\title{
Supply chain of the imported ginseng medicinal plant materials for the pharmaceutical industry of the Russian federation
}

\author{
T.M. Litvinova ${ }^{a}$, I.U. Glazkova ${ }^{a}$, S.A. Levagina ${ }^{a}$, E.N. Shalyapina ${ }^{a}$ and A.G. Sheina ${ }^{a}$
}

${ }^{a}$ Sechenov First Moscow State Medical University, 8 Trubetskaya St., bldg. 2, Moscow, 119991, Russian Federation

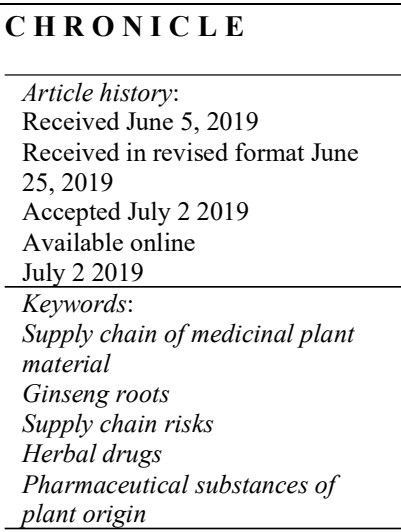
A B S T R A C T

\begin{abstract}
The article reviews methods of transportation for various types of imported medicinal plant materials of ginseng roots from China to the Russian Federation, with due consideration for risks. Logistic supply chains for ginseng roots have been developed and proposed based on the systemic method of research and the information analytical method. The optimal method for transportation of pharmaceutical substances of plant origin is chosen on the basis of the priority criteria for the cargo owner, as well as with due consideration for the peculiarities of the type of medicinal plant materials of ginseng roots.
\end{abstract}

(C) 2020 by the authors; licensee Growing Science, Canada.

\section{Introduction}

An important criterion for the successful sale of a medication and pharmacy assortment is to find the optimal way from the manufacturer to the consumer. Supply should be as gentle and thoughtful as possible in order to avoid transportation costs and losses. Supply of goods to the pharmacy organization assumes that each batch of medications has passed a quality check and was subjected to temporary storage in warehouses. Besides, it is possible that the medications were delivered from other countries or regions, which involved preparation of a significant amount of documentation. Logistic supply chains represent detailed descriptions of all goods transportation, taking into account the occurrence of risks and the search for optimal delivery from the source to destination. At first glance, building such chains may seem a relatively simple task: it is only necessary to decide where from, where to and how to transport the cargo. But there are new options with each stage of the logistic analysis that need to be considered for the successful implementation of the goal in reality (Bogoyavlensky, 2014). Statistics for the past five years indicate that $98 \%$ of the volume of dried ginseng roots in USD are supplied from China. The remaining parts are imported from Canada $(0.9 \%)$, South Korea $(0.7 \%)$, and Germany $(0.4 \%)$, but mainly in the form of finished dosage forms and combined medications. According to the ru-stat data, 5.45 tons were imported in the Russian Federation in 2017, of which China accounts for

* Corresponding author Tel.: 7(499)248-01-81

E-mail address: litvinova t.m@mail.ru (T.M. Litvinova)

(C) 2020 by the authors; licensee Growing Science. doi: $10.5267 /$ j.uscm.2019.7.002 
97.8\% (Export sand imports of Russia, 2019). As such, China is the leader in the supply of dried ginseng roots to the Russian Federation.

Ginseng roots were included in the USSR State Pharmacopoeia into 1968, and later into the Russian State Pharmacopoeia as well. They are currently included in the State Register of Medicinal Products (State register of medicines, 2019) and the State Pharmacopoeia of the Russian Federation XIV edition (the State Pharmacopoeia of the Russian Federation XIV edition (SPRF XIV ed.) Pharmacopoeial Monograph 2.5.0013.15 "Panacis ginseng radices". Wild ginseng is listed in the Red Book of the Russian Federation and protected by the Convention on International Trade in Species of Wild Fauna and Flora (2015).

Ginseng roots are valuable medicinal plant materials, which are in demand by many pharmaceutical companies for their processing into finished dosage forms (Hu, 1976; Harkey et al., 2001). Such industrial factories include Parapharm LLC (Moscow), Vifitekh (Moscow Region), Ivanovo Farm. Factory OJSC (Ivanovo), Kamelia (Moscow region), Genel Trade LLC (Kaluga region), Vis LLC (Moscow), and other enterprises engaged in the production of biologically active food additives and cosmetics. As such, there is a concentration of production mainly in the central region of the Russian Federation, and a challenge of transporting medications from China to Moscow for further distribution to manufacturing plants emerges.

A risk in the logistic system is an unfavorable event that can lead to deviation of the actual parameters of the logistic flows from the target output. The main risk during the transportation of ginseng roots is its improper storage during transportation. This necessitates control over the actions of transport companies at each stage of delivery (Brodetsky et al., 2010).

According to SPRF XIV ed., packaging must ensure protection of medication during its storage and transportation from damage, losses, and negative effects of environmental factors (temperature, humidity, light). Packaging must be uniform in type for each batch of raw materials; clean, dry, with no odor. The materials from which the packaging is made must be durable, light, chemically and physically indifferent when in contact with medication (Panacis ginseng radices, n.d.). The following types of packaging are used for the dried medication Panacis ginseng radices: woven bags (raw material weight no more than $50 \mathrm{~kg}$ ), paper laminated bags (raw material weight no more than $15 \mathrm{~kg}$ ), plastic bags (raw material weight no more than $15 \mathrm{~kg}$ ), oblong bales made from fabrics (raw materials weight not more than $50 \mathrm{~kg}$ ), plywood boxes (raw material weight no more than $30 \mathrm{~kg}$ ), etc. Panacis ginseng radices medication should be transported in dry, clean, with no odor, covered vehicles, or in containers (GOST 6077-80, 1980).

It must be noted that packaging, transportation, and storage of fresh ginseng roots have their peculiarities. According to the regulatory documentation, fresh medication Fresh cultivated ginseng root is packed in wooden boxes with holes in the end and side walls. The weight of roots in one box should not be more than five kilograms. The box is lined with a cloth inside when used for ginseng roots packing. A layer of moistened sawdust is made at the bottom of the box, then the first layer of roots goes, which is also filled with sawdust, and so on. The box should be edged with steel packing tape $0.7 \mathrm{~mm}$ thick and $20 \mathrm{~mm}$ wide, sheathed with packing tissue, and sealed. Ginseng roots are stored in a dry closed area at a temperature of $3-8{ }^{\circ} \mathrm{C}$ for not more than five days (GOST 23938-79, 1980). These peculiarities must be taken into consideration when choosing a mode of transport.

\section{Methods}

Logistic supply chains for ginseng roots have been developed and proposed for the pharmaceutical industry of the Russian Federation based on the systemic method of research and the information analytical method. 


\section{Results and discussion}

It is known that the first stage of importing the medication involves planning of the procurement volume and preparation of the necessary documents. It is followed by a challenge of the medication transportation from China to the Russian Federation. Let us compare the possible ways of delivery:

1) Container shipping by sea. Delivery times depend on the port of destination. For example, it will take a cargo from Shanghai less than a week to reach Vladivostok or $20-25$ days to the Black Sea ports via the southern sea route, and $40-45$ days to St. Petersburg via the northern sea route. Add the time for customs clearance in the northern capital (2 days) and that for delivery to Moscow ( 2 days), and get about 50 days as a result. This is how long the cargo will be in transit, including the customs and transport procedures. However, this way is not always available due to climatic conditions.

2) Truck haulage. This method of delivering cargo from China is especially popular in the Russian regions bordering the People's Republic of China, and transportation does not take long.

3) Air transportation is the fastest, most reliable and safest, most mobile, but also the most expensive type of delivery. Even taking customs clearance and delivery of goods from the terminal to the recipient's warehouse in Moscow into account, the delivery will take only 3 days on average ( 5 days from Guangzhou to Domodedovo).

4) Rail transportation. A stable and consistent delivery method that does not require unnecessary cargo transportation, since there is a single connecting railway network between major cities of the Russian Federation. Difficulties can arise only in the event of adverse weather conditions, but they actually must be taken into account in any mode of transportation.

According to the statistics of the freight forwarding companies in the Russian Federation for November 2018, the average transportation cost for ginseng medication with a weight of 5.45 tons amounted to at least $\$ 1,200$ by truck haulage, about $\$ 1,850$ by rail, and at least $\$ 6,860$ by air.

The optimal variant of the logistic supply chain of ginseng roots medication from a Chinese manufacturer to the warehouse of a Russian medication manufacturer is presented in Fig. 1.

It follows from the supply chain that several options are available for delivering finished dosage forms to Central Russia: it can be accomplished either without transshipment or with unloading and changing transport in such hubs as Yekaterinburg, Irkutsk, Krasnoyarsk, etc. The route will depend on transportation financing, human factor, time interval, and weather conditions. Vladivostok is the best city to accept the imported finished dosage forms, since it has the necessary infrastructure for further transportation (warehouses, airport, railway station, and seaport). There is another option for delivering the imported finished dosage forms, which is delivering cargo by rail to Heihe (China) and crossing the border by the Zeya River. In this case, additional financial costs emerge for loading and unloading the finished dosage forms from railway to trucks, then to the sea transport, and then back to trucks (Fig. 2). 


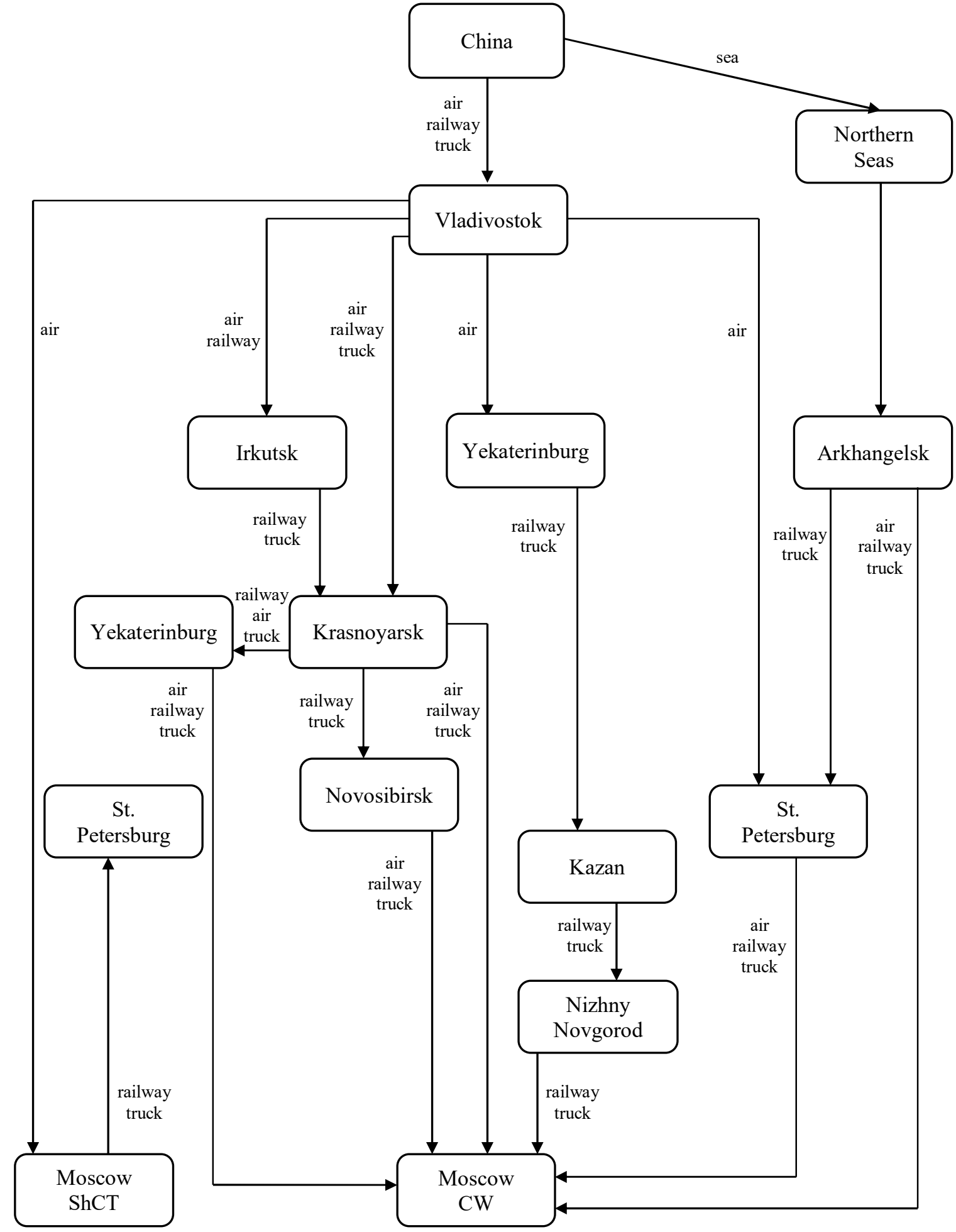

Fig. 1. Logistic supply chain for the finished dosage forms of ginseng roots from China to the warehouse of the medicine manufacturer in the Russian Federation

railway - railway transport

air - air transport

$\mathrm{CW}$ - central warehouse truck - truck haulage

sea - sea transport

ShCT - Sheremetyevo Cargo terminal 


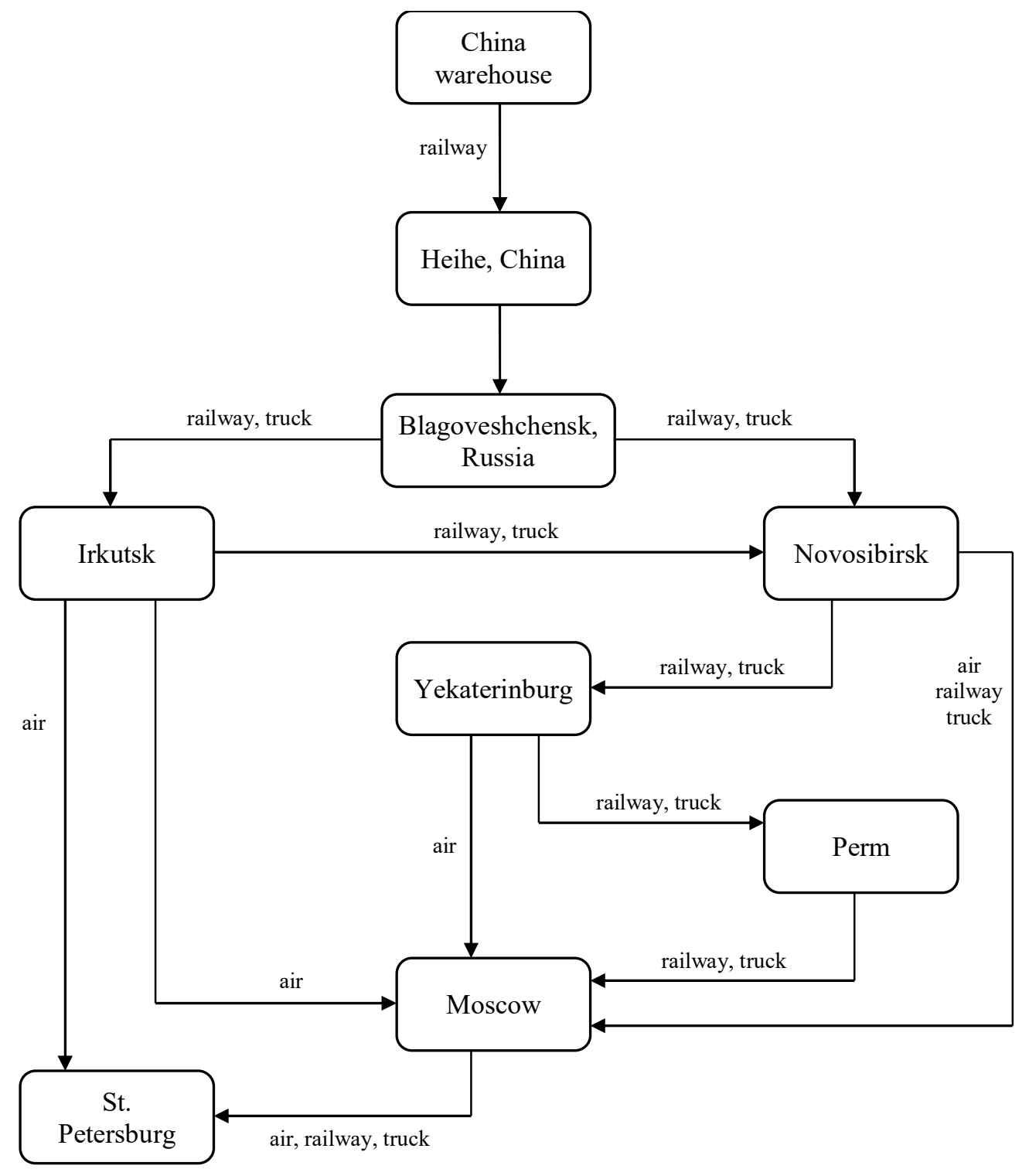

Fig. 2. Logistic supply chain for the finished dosage forms of ginseng roots from China through Blagoveshchensk, Russia

railway - railway transport

air - air transport

Russia - Russian Federation

$$
\begin{aligned}
& \text { truck - truck haulage } \\
& \text { sea - sea transport }
\end{aligned}
$$

Intermodal transportation combining air transport mode and trucking haulage is the fastest way to deliver finished dosage forms of ginseng roots from China to the central part of the Russian Federation. However, a significant disadvantage of this transportation option is its high cost, since air transportation implies additional fuel surcharges and the airport warehouse costs. This type of transportation suits best for the delivery of fresh ginseng roots that are good for no more than five days. Such an expensive type of transportation can be paid back only when purchasing a large volume of imported raw materials with a significant discount. The cheapest way to deliver the finished dosage forms of ginseng roots is by sea. This is the best way when there are no time constraints on storing and transporting the finished dosage forms, and the company has a large turnover and limited budget. This transportation mode can be used to deliver the finished dosage forms of dried ginseng roots. In this case, cargo can be delivered directly from the Chinese sea port to Arkhangelsk by northern seas, which are also free from piracy. 


\section{Conclusion}

As such, the supply chains to deliver the finished dosage forms of ginseng from China to the Russian Federation are created, which depend on the following criteria:

1. Type of medicinal plant material of ginseng root - fresh or dried.

2. Urgency of transportation.

3. Amount of funds allocated for the transportation of medicinal plant materials.

4. Seasonal availability of the transportation route.

\section{Acknowledgement}

The publication has been prepared with the support of the "Russian Academic Excellence Project 5100" (“Sechenov First Moscow State Medical University Program 5-100”).

\section{References}

Bogoyavlensky S.B. (2014). Teoreticheskiye i prakticheskiye aspekty prinyatiya resheniy v usloviyakh neopredelennosti i riska [Theoretical and practical aspects of decision-making in the context of uncertainty and risks]. SPb.: SPbSEU, pp. 9-10.

Export sand imports of Russia by goods and countries (2019). Access mode: http://ru-stat.com/

State register of medicines (2019). Access mode: http://www.grls.rosminzdrav.ru/ Default.aspx

The State Pharmacopoeia of the Russian Federation IV edition 2.5.0013.15 «Panacis ginseng radices». Types of wild fauna and flora falling under the Convention on International Trade in Endangered Species of Wild Fauna and Flora, dated March 3, 1973 (CITES) (2015). Access mode: http://www.consultant.ru/document/cons_doc_LAW_178556/ 0984f556763219422c25f99141d668801721591f/

Brodetsky, G.L., Gusev, D.A., Elin, E.A. (2010). Upravleniye riskami v logistike [Risk management in logistics: guide for students of universities]. Moscow: Publishing center "Academy", $192 \mathrm{p}$.

GOST 6077-80 Medicinal plant material. Packaging, labeling, transportation and storage (1980). Access mode: http://docs.cntd.ru/document/1200022935.

GOST 23938-79 Fresh cultivated ginseng root. Technical conditions (1980). Access mode: https://allgosts.ru/11/120/gost 23938-79.

Harkey, M. R., Henderson, G. L., Gershwin, M. E., Stern, J. S., \& Hackman, R. M. (2001). Variability in commercial ginseng products: an analysis of 25 preparations. The American Journal of Clinical Nutrition, 73(6), 1101-1106.

Hu, S. Y. (1976). The genusPanax (ginseng) in Chinese medicine. Economic Botany, 30(1), 11-28.

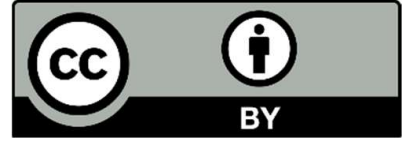

(C) 2019 by the authors; licensee Growing Science, Canada. This is an open access article distributed under the terms and conditions of the Creative Commons Attribution (CC-BY) license (http://creativecommons.org/licenses/by/4.0/). 